\title{
Proactive Public Disclosure: A new regulatory strategy for creating tax compliance?
}

DOI 10.1515/ntaxj-2015-0009

Received Aug 07, 2015; accepted Nov 10, 2015

\begin{abstract}
This article discusses proactive public disclosure of taxpayer information and how this may form a new strategy for securing tax compliance by tax administrators. It reports a case study from the Danish Customs and Tax Administration in which consumers of services-over a short period of time-were informed about businesses' lack of value-added tax (VAT) registration. Our approach to the case is twofold: First, the article lays out a legal analysis of the disclosure practice, and second, the article presents an organizational analysis of why the practice was initiated. The analyses show that using proactive public disclosure is compatible with the Duty of Confidentiality, but incompatible with Good Public Governance. Furthermore, the analyses show that there are a number of strong organizational rationales for using proactive public disclosure, despite its apparent incompatibility with Good Public Governance. The article is innovative in that it combines a legal and organizational approach to analyse a new regulatory strategy within tax administration.
\end{abstract}

Keywords: Public disclosure; tax administration; public law; organization; tax compliance

\section{Introduction}

Every country has a specific set of rules and regulations that govern societal interactions. If citizens, associations, and corporations comply with these rules and regulations, these can interact with one another without interference from government authorities. If, however, rules and regulations are violated, government authorities need to act to stop and/or prevent misconduct. It is such governmental intervention that this article is about, and the specific area of government in focus is tax administration and its

Karen Boll: Associate Professor, PhD, Department of Organization, Copenhagen Business School; E-mail: kbo.ioa@cbs.dk Michael Tell: Associate Professor, PhD, Law Department, Copenhagen Business School; E-mail: mt.jur@cbs.dk accompanying tax legislation. Tax administration and legislation is an area filled with challenges and prioritizing. Tax rules and regulations are not always complied with, either because of involuntary mistakes or deliberate fraud. The resources from the tax administration to govern and secure compliance are scarce and in need of constant efficiency improvement.

In order to create an overview about how a tax administration navigates this complex regulatory space, this article presents an example of tax fraud governed by the Danish Customs and Tax Administration (SKAT). In short, the fraud in focus concerns businesses that, for various (serious) reasons, have either been denied a value-added tax (VAT) registration or had their VAT registration cancelled by SKAT. Yet, instead of bringing their VAT-related activities to a standstill as prescribed by the tax administration, these businesses continue doing "business-asusual". This implies that the businesses issue unauthorized invoices levied with VAT to their customers without paying this VAT to SKAT. Enacting such a practice is a deliberate offence of the Danish VAT laws: a business cannot issue VAT-levied invoices without a valid registration.

In this article, we analyze a new regulation strategy used by SKAT to create compliance among these VATfraudulent businesses. We show that the new regulation strategy poses a number of both legal and organizational challenges. In the legal analysis, we show that the strategy is compatible with the Danish Duty of Confidentially but is incompatible with Good Public Governance. In the organizational analysis, we show that the strategy is expedient because it motivates third parties to participate in the regulation and because it cost-efficiently targets a group of "hard-to-reach" VAT fraudsters. The analysis shows the value of combing a legal and an organizational perspective when analyzing a regulation strategy as it puts forth different elements of the strategy and different reasons for why-or why not-using this regulation strategy is legitimate. We believe that combining legal and organizational points of view in an analysis is contributional because civil servants' everyday priorities when regulating businesses' frauds are not based on only either legal or organizational considerations (e.g., Lamb (2005); McKerchar 
(2008); McKerchar (2010)). Rather their everyday tasks, decisions, and priorities are made with attention to both. Therefore, it makes sense to contain this complexity in an academic analysis of the present day regulatory efforts.

Interdisciplinary research implies that different methodologies and research designs are being combined. In our case, we first provide an example of classic legal research that builds on identifying relevant laws and statutes, in order to analyze the legitimacy of the new regulation strategy. The legal method is based on the Scandinavian legal realism, that is, the law can only be explained in terms of observable facts and the study of such facts ${ }^{1}$. Realists define law as a prediction of what the courts will decide. Norms are, therefore, considered to be laws because they are felt by the judge(s) to be socially binding and, therefore, obeyed. A norm is valid if it is predicted that the Court will apply it. However, in addition to the Courts, there is the Danish Parliamentary Ombudsman (similar to the Swedish Justitieombudsmannen), whose role is to oversee the public administration. The Ombudsman is to assess whether the authorities act in contravention of existing legislation or otherwise commit errors or derelictions in the discharge of their duties ${ }^{2}$. The Ombudsman is, therefore, not restricted to contravention of the legislation, but unlike the Courts it can also look into other errors and derelictions. The authorities do, therefore, not only have to act in accordance with existing legislation but also with norms as stated by the Ombudsman (Good Public Governance) (Bønsing $(2008,424)$ ). The Ombudsman may state criticism of the authorities and recommend that the authorities reopen a case or change their decision (Bønsing (2013, 403, note 52)).

Next, we have the organizational analysis based on qualitative methodology. This builds on interviews with tax inspectors, observations of their work, and internal administrative documents. In this analysis, the focus is on how meanings and interpretations of work are constructed by the tax inspectors and how the inspectors perceive the new regulation strategy. We are aware that we combine research designs that are normally not juxtaposed. While we have chosen to let our different analyses be presented at length, we have chosen to omit detailed methodological considerations because we want the attention of this arti-

1 Scandinavian legal realism was founded by Hägerström (the Uppsala-school) and later evolved by Olivecrona and Lundstedt from Sweden and Ross from Denmark. See, for example, Evald and Schaumburg-Müller (2004) and Nielsen and Tvarnø (2011).

2 Cf. Section 55 of the Danish Constitutional Act and Section 7 of the Ombudsman Act. cle to primarily be on the substance, that is, the analysis of the new regulation strategy. As a consequence, further methodological considerations are included in the footnotes.

Article outline: Section 2 introduces the tax administration's new strategy for regulation-called the proactive public disclosure. Section 3 analyzes the legal framework for this proactive use of information. Section 4 analyzes the organizational framework for the strategy. Finally, Section 5 includes the conclusion and a summary of the article's main arguments as well as a discussion of the viability of the new regulation strategy.

\section{The new regulation strategy-proactive public disclosure}

In November 2011, SKAT publicly declared that it would embark on a new strategy to secure compliance in a number of more complicated cases of VAT fraud, the key idea in this strategy being the proactive public disclosure of a business' (lack of) VAT registration ${ }^{3}$. In Denmark, it has long been a problem that some businesses that had either been denied VAT registration or their VAT registration cancelled by SKAT continued doing "business-asusual". From the tax administration's perspective, these businesses engage in a vicious cycle of fraudulent behavior. First, these businesses act as though they have a valid VAT registration from SKAT in relation to their customers. Second, they do neither inform SKAT nor pay the 25 pct. VAT on their invoices to SKAT, thereby getting a "free" additional 25 pct. profit on their products and services. Ironically, they would not be able to pay this VAT because they are not VAT registered. Hence, these businesses are using the "legitimacy" of the VAT-levied invoices to commit fraud.

The normal regulatory procedure from SKAT regarding such fraudulent behavior has been to initiate proceedings against the businesses. In this classic setup, it was the fraudulent business itself that received reminders, checkups, and inspection from the tax administration. In many cases, however, this inspection strategy has not been effec-

3 See Press Release from SKAT (03.11.11), "SKAT fortæller det til kunderne". The introduction to the case also builds on the qualitative fieldwork conducted by one of the article's authors. See footnote 26 for further details on this fieldwork as a background for introducing the case. 
tive in preventing the fraud from taking place. Inspectors recall that on several occasions, they observed that businesses continued their "non-VAT-registered" business activities, despite repeated orders requiring them to stop.

As a result, SKAT decided to introduce a new (and more radical) inspection strategy through which selected consumers were actively informed of the fact that they were purchasing products or services from a non-VATregistered business. In principle, information about a business' VAT registration is available for public access on SKAT's homepage, but the challenge is that not many consumers actually look into the VAT registration of businesses-especially private consumers tend not to do it. Hence, SKAT started to actively provide consumers with information about the missing VAT registration-information that the consumers, in principle, could find themselves by accessing the databases of VAT-registered businesses. The aim of providing this information to consumers was to prevent consumers from purchasing products and services from fraudulent businesses, thereby reducing these businesses' cash flows and ability to continue operation. From the tax administration's perspective, this public disclosure strategy turned out to be successful because it made several businesses move toward compliance-a point that we will return to in the analysis part of the paper.

We describe the new regulation strategy as radical because it does not target the actual offenders of the law, the non-VAT-registered businesses, but rather targets and seeks to engage and motivate a third party to take action. This third party is the consumers who have paid their VATlevied invoices. They can be the indirect key to prevent that the cash flow of the fraudulent businesses increases because the consumers can cease purchasing. While many tax inspectors were satisfied with this new regulatory strategy, the permission to inform the consumers was withdrawn within a few months by the juridical department in SKAT, an incident we will also return to. In 2012, the inspectors expressed that they found this withdrawal frustrating and that they would push to reopen the permission to proactively inform consumers. However, the practice has so far not been reopened.

As described, the purpose of this article is to examine this new strategy to (re)create compliance. However, we are not focusing on whether or not a business is compliant (e.g., VAT compliant) or go into detail about why a certain VAT registration has been cancelled or denied. Instead, the article is based on a situation in which a business is per se not VAT compliant, and our analysis focuses on SKAT's strategy of proactively using information in such situations in order to obtain compliance. What we find interesting is the legal base behind this proactive use of in- formation and the organizational developments that first gave rise to this practice. The analysis results in a discussion about whether and how a proactice public disclosure can be a viable future strategy for preventing fraud and increasing compliance, not just in this case but also in similar cases in which tax administrations are challenged to find new ways of regulating tax fraud.

\section{Legal Framework-Taxpayer versus the State}

The Danish Ministry of Taxation administers income taxes, VAT, and customs and is responsible for both legislation and tax policy (The Department) and for the administration and collection of taxes (SKAT). SKAT's main purpose is to assess the correct amount of taxes to be paid and to collect those taxes ${ }^{4}$. As with any other public administration authority, SKAT has to comply with the law and must, therefore, align the effective collection of the amount of taxes with the limits of the law, such as protection of privacy.

Alongside the law is another system of rules and principles: Good Public Governance ("god forvaltningsskik"). The principles of Good Public Governance are derived from ethics and based on fundamental values of humanity and society, for example, behavior patterns between people and groups of people (proper behaviour). It is good public governance to respect the taxpayer as an independent and equal person and act with the necessary discretion. Good Public Governance counterbalances the unilateral purpose of effective tax compliance (assessment and collection etc.) and is based on the overall objective of how the public administration is to behave and act (See Gammeltoft-Hansen (2010); Andersen (2014); Revsbech (2010); Mørup (2012); Bønsing (2013)).

SKAT has access to a large amount of information regarding taxpayers, some of which is more sensitive and personal than other. Access to information is vital for making a correct tax assessment. However, information is not only valuable for SKAT and the taxpayer but sometimes also for third parties such as customers and other stakeholders (See Koerver Schmidt (2015)). Disclosing tax information to the public (third parties) can, therefore, have a positive effect on tax compliance according to the Danish Ministry of Taxation, and the fact was a key argument for

4 See the Ministry of Taxation's own description: http://www.skm. $\mathrm{dk} /$ ministeriet/ministeriet/skatteministeriets-koncern/ 
making selected tax information in relation to Danish companies available on SKAT's Web site in $2012^{5}$.

However, simply making tax information available does not necessarily mean that the information is actually attained by the public, the stakeholders, or the actual consumers. Instead, information used in an even more proactive way can have a higher positive effect on tax compliance if the information is proactively (without request) given to the relevant stakeholders such as consumers, as was the key idea behind the strategy of proactive public disclosure. The question we wish to raise in the following section is whether or not such proactive use of public information by SKAT is consistent with the law on Duty of Confidentiality and/or Good Public Governance.

\subsection{Duty of Confidentiality}

In Denmark, the public administration is subject to the Duty of Confidentiality in relation to confidential public or private matters, including those regarding taxes ${ }^{6}$. Information is confidential if classified as such by the law, or when it is necessary to keep the information confidential due to legitimate public or private interests ${ }^{7}$. Furthermore, SKAT is subject to unconditional confidentiality in relation to an individual's financial, professional, or private affairs ${ }^{8}$. According to the Danish Administration Act, SKAT cannot disclose information covered by the duty of confidentiality to anyone other than to the individual himself, unless there is specific legal basis for it, for example, consent from the individual or if the information is already available by request according to the Danish Administration Act.

Information on VAT registration or nonregistration, the latter being relevant to our concern here, is not considered to be confidential because such information is not by law classified as confidential or necessary to be confidential because of substantial public or private interest (See also Gammeltoft-Hansen et al. (2010, 473); Basse and Jørgensen $(1988,112-114))$. On the contrary, the tax authority can disclose information reading VAT registration to the public. The VAT system is built on providing access to knowledge about whether or not a business is VAT registered, and such information can be disclosed verbally, in

5 Cf. Section 17, Para. 2 of the Danish Tax Administration Act. Further see the general comments in section 3.5 in Bill L 173 2011-12.

6 Cf. Section 27, Para. 1 of the Danish Administration Act and Report on Duty of Confidentiality no. 998 1984, p. 76.

7 Cf. Section 152, Para. 3 of the Criminal Code.

8 Cf. Section 17, Para. 2 of the Danish Tax Administration Act. writing, or electronically 9 . The information is, therefore, through databases, already available to the public in Denmark and within the $\mathrm{EU}^{10}$. Furthermore, according to the Act on Processing of Personal Data, such personal information can be collected, used, and disclosed, if necessary, to create compliance with a legal obligation, for example, the Danish VAT Act. Disclosure of information as stated in the Act on Processing of Personal Data is not in conflict with neither the Danish Administration Act nor the Danish Tax Administration Act ${ }^{11}$. A disclosure of whether or not a business is VAT registered, which is the core of the proactive public disclosure strategy, is, therefore, consistent with the Danish Administration Act, the Danish Tax Administration Act, the Danish VAT Act, and the Act on Processing of Personal Data.

However, the Danish VAT Act Section 51 b also states that the tax authorities can disclose such information when the request specifies the CVR-no., the name, or the address of the company in question. The issue is, therefore, not whether or not information on VAT registration is confidential or not, as it is clearly not, but whether or not the tax authorities can proactively disclose such information without any request from the stakeholder. The question that remains is whether tax inspectors actually can "come knocking on your door" saying that "that carpenter who just fixed your garage has no valid VAT registration and he is not paying the VAT that he just collected from you.” Is that Good Public Governance?

\subsection{Proactive Use of Publicly Available Information}

Good Public Governance is both a historical and current cornerstone of public administration and an essential link in the interaction between public administration and citizens (See Gammeltoft-Hansen et al. (2010, 617), Mørup (2012, 205), Rønsholdt (2012, 283)). The public administration is, therefore, always to act in a polite and respectful manner toward the citizens (See Gammeltoft-Hansen (2010)). Furthermore, the public administration need to ensure that the process of personal information does not lead to an infringement of the taxpayer's integrity, thereby creating reassurance of the public's processing of personal

\footnotetext{
9 Cf. Sec. $51 \mathrm{~b}$ of the Danish VAT Act. 10 See the Danish Tax Authorities' website (https://www.skat. dk/SKAT.aspx?oId=71454) and the European Commission's website (http://ec.europa.eu/taxation_customs/vies/). 11 See Report from the Ministry of Justice, no. 1516/1010, p. 23.
} 
information, hence trust (See also Blume (2006, 621)). Therefore, any public administration unit, such as SKAT, cannot use personal information, as it may suit SKAT. Whether or not the proactive public disclosure of a business' (lack of) VAT registration is legitimate or serving a too narrow agenda is illustrated in the two cases from the Danish Parliamentary Ombudsman described in the following text.

In case FOU no. 2005, 309, the Danish Consumer Ombudsman (specifically the Consumer Authorities) publicly disclosed the name of an airline that the Danish Consumer Ombudsman had just reported to the police for an infringement of the Danish Marketing Act. The Danish Parliamentary Ombudsman found that even though the duty of confidentiality had not been violated, a public administration cannot, without legal basis or other valid reasons, disclose information that can be damaging for a business. The disclosure of nonconfidential information, therefore, requires the public administration to follow the principle of Good Public Governance, meaning that the disclosure must be justified and be proportionate to the purpose of the disclosure ${ }^{12}$. Further, it is assumed that public disclosure is not compatible with Good Public Governance if the purpose is to publicly expose the offender (taxpayer) (See Mørup $(2014,271))^{13}$. In FOU no. 2005, 309, the Danish Parliamentary Ombudsman did not express criticism because of the Danish Consumer Ombudsman being legally obliged to represent consumer interests and to inform the public in relation to matters that are processed by the Danish Consumer Ombudsman or the Courts, which are necessary for understanding the Marketing Practices Act. Furthermore, the Danish Parliamentary Ombudsman did not express criticism because of the fact that the Danish Consumer Ombudsman disclosed the information on the basis of an individual assessment.

FOU no. 2005, 309 illustrates that the public administration cannot disclose or expose a taxpayer without legal basis or other valid reasons. The sole purpose of SKAT's threat to disclose information on the non-VAT registration is to expose the taxpayer for the third parties (consumers) to see, and with that force, the taxpayer into compliance. Further, it should be noted that the fraudster is the business (taxpayer), not the customer ${ }^{14}$. The issue at hand is, therefore, between SKAT and the fraudster business. The threat of involving third parties, consumers, is only used to create compliance between SKAT and the fraudster, cases

12 See Report from the Ministry of Justice, no. 1516/1010, p. 63. 13 See Report from the Ministry of Justice, no. 1516/1010, p. 116. 14 See Section 3 of the Danish VAT Act and recently SKM2012.65.ØLR. in which third parties are used as means. This does not seem to be a valid reason for disclosure, as also illustrated in the following case FOB no. 1991, 185.

In FOB no. 1991, 185, a municipality in Denmark introduced a particularly prominent car to be used for the collection of unpaid taxes. The mayor was quoted saying that the car should be seen by neighbors, friends, and acquaintances and thus get people to pay their tax debts (e.g., compliance). First, the Danish Parliamentary Ombudsman found that such a method was not in line with the Danish Administration Act because confidential information was given to the public (by the car being very prominent). Second, the Ombudsman found that it was clearly contradictory to the Danish Marketing Practices Act Section 1 to use threats as means in obtaining payments of debt. Although the Danish Marketing Practices Act does not apply to municipalities, the Ombudsman found it unfortunate that the municipality could use methods that were prohibited in private debt collection, thereby confirming that good practice rules must take into account the prevailing behavior that is perceived as proper (Bønsing $(2004,1))$. Similarly, it was not considered to be a respectful procedure to send recovery letters in envelopes with a prominent labeling, because it could also be perceived as threatening or abusive. Additionally, The Ministry of Justice found the methods used by the municipality not to be compatible with the fundamental principles of administrative law and Good Public Governance. The Ombudsman urged the municipality to stop using the prominent car and the prominent labeling, which the municipality did.

The proactive use of information in FOB no. 1991, 185 has similarities to our case of proactive use of public information on VAT registration. In both the cases, information is used as a threat to ensure taxpayers' compliance, and because such behaviour is not compatible with good marketing practice for private debt collectors, it does not seem to be compatible with Good Public Governance for SKAT.

To sum up, the proactive public disclosure of non-VAT registration does seem compatible with the duty of confidentially but incompatible with Good Public Governance. As stipulated in Kant's central practical doctrine, "Always recognize that human individuals are ends, and do not use them as means to your end" (Popper $(2013,98)$ ).

Recalling the introduction, the practice of proactively disclosing information about a business' lack of VAT registration was put to a standstill only after few months. From a legal perspective, such a standstill makes sense, and therefore, it cannot be considered as Good Public Governance for a public administration to use threats and other people as means to obtain tax compliances of a taxpayer. In other words, tax inspectors should not walk around ac- 
tively sharing information with third parties about specific noncompliant businesses. Such behavior will presumably require explicit legal basis and/or changes to what is considered to be Good Public Governance.

The tax inspectors have acknowledged the legal reasoning behind this decision. However, on the other hand, they support the proactive use of information from an organizational perspective and wish the practice to continue.

\section{Organizational Framework}

While the previous section examined the legal aspects of a proactive public disclosure, this section analyzes why this administrative practice was initiated in the first place from an organizational perspective ${ }^{15}$. The argument is that the decision to use a proactive public disclosure is connected to (1) cuts in resources in SKAT, (2) trend of increasingly engaging and involving external stakeholders in the regulation, and (3) the specific segment of highly fraudulent business owners. These arguments will each be discussed in the following sections.

\subsection{Cuts in resources}

In order to understand the decision to use proactive public disclosure, a brief contextual explanation of SKAT must be provided. In 2005, approximately 10,700 people were employed in the administration, compared to 6,400 in 2012, constituting a decrease of 40 percent. Within the different "core tasks" of the tax administration (i.e., statement of accounts, guidance, inspection, and collection), inspection, the area to which the VAT-registration belongs to, has been cut with 38 per cent from approximately 3.400 man-years in 2006 to 2.100 man-years in 2011 (Rigsrevisionen (2012, 12 and 17)). In other words, the man-years allocated to inspection have been cut significantly over the past years.

15 Knowledge about the organizational aspects of the case stems from a two months qualitative data collection conducted by one of the authors in the Danish Customs and Tax Administration, spring 2012. This data consists of internal administrative documents and public documents, 18 in-depth interviews with tax inspectors, and observations of office work. Over the period, the researcher was connected to a team of tax inspectors responsible for the proactive public disclosure and was allowed to follow parts of the inspectors' daily work. When referring to the case, it is this material that forms the background. For a broader ethnographic description of tax administration and for further elaborations on methodology, see Boll (2012, 2014).
To ensure and justify that such a reduced work force could still accomplish SKAT's main purpose of assessing the correct amount of taxes to be paid and to collect those taxes, a variety of initiatives were developed. For instance, strategies for a more digitalized tax administration, responsive regulation, and a more risk-based selection of taxpayers to audit were developed ${ }^{16}$. These strategies aimed to develop automatic, informative, and targeted administrative procedures.

Another central and globally widespread initiative that also inspired SKAT was the tax administrations' need to conduct more proactive guidance and service to prevent faults, instead of conducting reactive audits, an agenda forcefully advocated by the OECD (OECD $(2004,2010)$ ). The rationale behind this is that doing reactive audits is a costly practice in terms of man-years and targets only a few selected auditees. In contrast, when undertaking proactive guidance and service, it is possible to target many taxpayers through campaigns and to up-front prevent potential faults and tax frauds. Hence, from the mid-2000s, SKAT actively started to emphasize doing more guidance and service to prevent future noncompliance, a strategy that was closely linked to the reduction in man-years; it was simply not possible to do as many audits as before with the reduced staff. Organizational readjustments and novel approaches to secure compliance were needed, and the practice of proactive public disclosure was found to be a cheap and effective tool to ensure compliance, which is also described in the following.

\subsection{Coproduction, engagement, and involvement of external stakeholders}

A key element in the proactive guidance and service strategy is engagement and involvement of external stakeholders in securing compliance. This agenda has been described and blueprinted in the OECD report Together for better outcomes: Engaging and Involving SME Taxpayers and Stakeholders (2013). The report is produced by OECD's Forum on Tax Administration for tax administrations and emphasizes the potential for creating better tax compliance by initiating cooperation between tax administrations and external stakeholders and states that "On their own [the revenue bodies] are not capable of addressing

16 A lot of these initiatives were originally inspired by John Braithwaite's research on responsive regulation (Braithwaite (2003)) and by Valery Braithwaite's research on motivational postures and segmentation originating in Australia (Braithwaite (2003)). 
the scale of the challenge revenue bodies face, particular in the wake of the global financial crisis". (Ibid. 3). The message is that revenue bodies increasingly need to look outside their own organizations to use the knowledge and resources of both taxpayers and other stakeholders to achieve higher tax compliance. By doing this, there is a potential for improved outcomes and services, as well as reduced costs (Ibid. 3).

It is not only the OECD that promotes using resources of taxpayers and other stakeholders to create compliance; this is also advocated by a number of public administration scholars under the heading "coproduction". One prominent advocate is John Alford, Professor of Public Sector Management at the Australian and New Zealand School of Government (ANZSOG). Alford is also a frequent guest speaker at Copenhagen Business School's Master of Public Governance programme, where several of SKAT's managers do their education. Alford defined coproduction as any active behavior by anyone outside a government agency that is conjoint with agency production and that creates private or public value in the form of either outputs or outcomes (Alford $(2009,23)$ ). Alford stated that there is a compelling reason for public managers to engage in coproduction, namely, that the external stakeholders contribute through time and effort and are able to enhance the performance and reduce the costs of public agencies (ibid. 9). Bill Ryan further added that coproduction is often initiated when other forms of service delivery have not achieved the objectives in the relevant policy area (Ryan (2012, 319)).

While coproduction is a common concept used to describe these collaborative governance efforts, other researchers talk about interactive governance (Torfing et al. (2012)), use of nongovernmental resources to foster regulatory compliance (Grabosky (1995)), policy networks (Rhodes (1997)), or distributed public governance (Flinders (2004)). All concepts describe the trend of moving from a classic steering and control approach in which the government regulates society through formal state actors to a more collaborative and interactive governance model in which a number of actors are engaged in achieving a set of objectives. This literature is interesting because it enables a description and analysis of the core of SKAT' proactive public disclosure strategy, namely, the engagement and collaboration with a third party, the consumer, in securing tax compliance.

As mentioned in the introduction, the shift to proactive public disclosure was initiated because the previous ways of enforcing compliance turned out to be inefficient, as the non-VAT-registered businesses kept doing "business-as-usual," despite the tax inspectors' au- dits. One major reason for the inefficiency, as also indicated earlier, was that there were simply too few inspectors. Considering the situation, it made sense to lift some of the "burden" of the state regulation onto the shoulders of the consumers by nudging (Thaler \& Sunstein (2008)) them to cease purchasing products and services from the VAT fraudsters. Hence, as Ryan noted, coproduction mobilizes external stakeholders because it reduces the use of public resources. In a public sector that is pressed for resources, this strategy is convenient as when the tax inspectors have proof of VAT fraud, they only have to pass on this information. The tax administration can present the information either as a threat to the sellers to inform the purchasers or simply by directly informing the purchasers, who can then decide whether they wish to continue doing business with the seller. In this setup, the tax administration shares pieces of information which then causes the purchasers and sellers in the market to react. The burden of complying with the rules and regulations is still weighing on the shoulders of the sellers/businesses. Yet, a new element is that the consumers are actively nudged, invited, or prompted to exert influence and participate in the regulatory practice should they wish to do so.

To illustrate these mechanisms, it is useful to look at a concrete case in which the tax inspectors used the strategy of proactive public disclosure ${ }^{17}$. The example presented here concerns a carpenter who did not have a valid VAT registration but was issuing invoices levied with VAT to his customers who were paying the carpenter in good faith. This fraud was detected by the tax inspectors and is a clear example of the fraud in question. Following the strategy of proactive public disclosure, the inspectors informed the carpenter that they would tell his major customers that he had no valid VAT registration and that he had not paid a total of 300.000 DKK in VAT to the tax administration, an amount that had been paid by these customers. After having received this message, or threat, the carpenter in a two weeks time paid both the VAT he had due, and updated his bookkeeping and got a VAT registration. Clearly, he did not wish his regular customers to be informed about the VAT fraud and the mere possibility that they would be made him swiftly begin to comply to the regulations.

The case illustrates a new way of regulating because the tax inspectors explicitly design a setup where the consumers are engaged in the regulation and where their power to act is steered by the tax inspectors who provide the information enabling the consumers to act. In this way,

17 This case was described in the interviews with the tax inspectors. See short introduction to methodology in footnote 15. 
the tax inspectors function less as direct authorities and auditors and more as meta-governors of the enforcement process. As Torfing et al. (2012) put it, "Public administrators are (...) recast as managers of interaction" (Torfing et al. $(2012,156))$. Defining this regulatory setup is important in that the tax administration is normally seen as a policy area in which formal control and governmental procedures are pivotal (Torfing et al. (2012, 4)). Traditional regulatory approaches relying on enforcement and retrospective audits is commonly used by tax administrations, a fact noted by the OECD when attempting to provide inspiration and guidance on how to engage and involve taxpayers and stakeholders in creating compliance (OECD (2013)).

The OECD states that there is a potential for improved outcomes, reduced costs, and improved services by engaging and involving external stakeholders (OECD (2013, 3)). Yet, this study shows that this new regulatory strategy also results in a number of challenges, particularly relating to regularity. The administrators can try to influence what the consumers do with the information they get, but they cannot fully control it. For instance, some consumers might act, others may not, and some might ask to get the services and products "off-record" to save the VAT, which in any case is not paid to the tax administration. Hence, a challenge is that the consumers can behave unexpectedly or simply ignore the push to act. This is problematic in a bureaucracy where citizenry, as Pollitt and Bouckart noted, expect regularity, justice, and impartial application of rules to citizens (Pollitt \& Bouckaert (2000)). Introducing regulation that relies on consumers' potential actions may jeopardize regularity because consumers decide how to react depending on their understanding of the risks and benefits involved.

\subsection{The specific segment of business owners}

Considering these challenges, one might wonder why the tax administration decided to use proactive public disclosure. Looking at who the noncompliant business owners are can add some nuance to this question. It should be brought to mind that either when SKAT denies business' request to get VAT registered or when it actively cancels an existing VAT registration, it is one of the most severe sanctions that the tax administration can impose. However, this can only be done in cases where the business in question, for an extended period of time, has not met its obligations of either (1) registering in the [tax] system, (2) timely filing and/or logging of requisite taxation information, (3) reporting of complete and accurate information (i.e., had a good record keeping), or (4) paying the taxa- tion obligations on time (e.g., OECD (2004)). As the tax inspectors explain in the interviews, the businesses whose VAT registration have been denied or cancelled may have received more than 30 letters from the tax administration concerning their registration, over an extended period of time. All these businesses have been through a long process in which service has been provided to guide them in the direction of compliance. If the process still ends with a denial of registration or a cancellation of an existing registration, the business owners are required to stop business activity promptly. They are informed that continuing any business activity constitute criminal liability, the penalty of which being fees or in the worst case, imprisonment for up to one and a half year.

The point with describing this process is to highlight that those business owners who continue to do "businessas-usual," meaning are still issuing invoices levied with VAT to their customers while not being registered are purposefully breaking the law. This is not something one can do "by accident" or "unintentionally", but is rather a practice that can only be considered a deliberate violation of the law. As the tax inspectors explain, these offenders are "tough ones" and they need to be exposed to the worst-case scenario to feel immediate consequences from the tax administration. Hence, public disclosure is only used against the business owners who have already been through a long process of service and guidance and who still deliberately choose to break the law. Furthermore, according to the tax inspectors, some of these business owners also distort competition because they sell services and products cheaper than the registered competitors in the same market-while others simply "pocket the VAT evaded". This also means that it can be a lucrative way of "doing business" and that the tax administrationand the society at large-loses large amounts of revenue. A caveat to this "lucrativeness" includes the administrative disadvantages of not being VAT registered; it prohibits the ability to reclaim input VAT, which adds 25 per cent to these businesses production costs. Yet, this disadvantage does not seem to prevent the VAT fraud from taking place, and in the larger sense, these offenders' activities risk weakening the public's perception of and trust in the tax administration. It can be seen as a threat to one's sense of justice and fairness to see these businesses operate.

In light of the above descriptions, we can see why regulation through proactive public disclosure is useful to the tax administration; it cost-efficiently targets a group of "hard-to-reach" fraudsters. By the use of relative few resources, it includes and activates consumers in a diffcult corner of the regulatory craft. A tentative evaluation by the tax inspectors of the proactive public disclosure ac- 
tivities showed that in approximately 70 per cent of the cases in which proactive public disclosure was used, the outcome was positive; it resulted in tax compliance among this group of offenders who had otherwise been difficult to reach ${ }^{18}$. The proactive public disclosure enabled the tax inspectors to meet their objective of determining the correct amount of VAT, taxes, and duties to be paid, and to collect these, within a challenging segment of offenders. While this may justify the practice of "naming and shaming" fraudsters, we still believe that the famous quote from Nelson Mandela should be kept in mind, "A nation should not be judged by how it treats its highest citizens but its lowest ones" (Mandela (1995)).

In sum, it is clear that proactive public disclosure is problematic from the viewpoint of Good Public Governance. To use third parties, the consumers, as means to obtain compliance and to use thinly disguised threats is not in line with Good Public Governance, as we have shown in Section 3. Yet, if we want to understand not only why this practice was brought to a standstill but also why it was initiated and why the tax inspectors wish to continue using this strategy, some of the points presented above can help with the explanation. In this regard, it is central that proactive public disclosure is a practice to be used only in the toughest cases to secure compliance by stopping the activities of deliberate offenders of the law who have been proven to be indifferent to "softer" enforcement methods. In light of the novel trends of engagement and involvement of external stakeholders and coproduction, SKAT's proactive public disclosure can be seen as an innovative and radical solution to a problem of pressed resources and severe VAT fraud. In other words, organizationally, there is a strong rationale for the use of proactive public disclosure.

Though we state that the strategy is "innovative and radical", it should be noted that the strategy does not flout the laws, for example, neither the Danish Administration Act nor the Danish Tax Administration Act. However, it is not in line with the norms of the behavior of a public authority, that is, Good Public Governance, which is a set of principles derived from ethics based on fundamental values and which states, for instance, that the public administration must act in a polite and respectful manner. What this means in practice can wary over time, and it is up for interpretation what constitutes "polite and respectful", as highlighted in Section 3. There we showed by comparing the case of proactive public disclosure to similar cases which were interpreted in different ways. Im-

18 This number is presented in several internal administrative documents from SKAT which evaluate the initiative. portantly, what we find intriguing is precisely that the tax inspectors in the case of proactive public disclosure did not flout laws. Instead, it was their considerations of the "softer" Good Public Governance principles that stopped their activities, considerations that at other points in time may be interpreted differently as they are not static.

Looking at the case within a broader timeframe, it is clear that direct engagement and involvement of external stakeholders in regulation is a relative new phenomenon within tax administration. Yet, from both the OECD report and the academic literature, one can infer that there are no signs indicating that coproduction and engagement will be less widespread in the future. Rather, it is described as a method that can be used to work smarter and more efficiently because regulatory resources outside the administrations are levied, which is also the rationale argued by the inspectors who are in favor of the method. Based on this, we assume that methods such as proactive public disclosure may become more widely used in the coming years. How strong the principles of Good Public Governance are in counterbalancing the more unilateral purpose of effective tax compliance in such a scenario, only time can tell. As we see it, the case thus also embodies a "battle" between professionals in SKAT-or on any tax administration. On the one hand, there are the legal experts with concern for the legal aspects-including Good Public Governance. On the other hand, there are the practitioners, that is, the tax inspectors on the floor. The latter are interested in using effective tools and strategies in order to obtain compliance. Both concerns must be counterbalanced and negotiated to enable legitimate and effective administration.

\section{Conclusion: Can "proactive public disclosure" be a tool for creating tax compliance?}

This article has examined a particular new regulation strategy, the proactive public disclosure. Based on law and organization studies, we have examined the legal base behind this practice and the organizational developments that enabled it. Our assumption has been that within public administration, legal and organizational considerations constantly interact to shape administrative practices. New tools and practices need both legal authority and organizational maturity. Through analyzing the case, we have first shown that it is in line with the Duty of Confidentiality to disclose the information but not in line with Good Public Governance. Second, we have shown that 
SKAT describes the strategy as expedient because it motivates third parties to participate in the regulation. From the perspective of the tax inspectors, the regulation strategy cost-efficiently targets a group of "hard-to-reach" VAT fraudsters. Currently, however, Good Public Governance does not allow neither using the threat of public hanging nor the actual proactive "public hanging" of the VAT fraudsters.

The analysis presents the trade-offs of everyday tax inspection regarding counterbalancing the concerns for Good Public Governance, especially the behavior of an administrative authority toward the individual tax payer and/or business, and the overall justice and effective assessment and collection of duties, VAT, and taxes. The question is whether or not the recent years' pressure on the overall justice and effective assessment and collection of duties, VAT, and taxes, owing to the cuts in resources in SKAT, should be counterbalanced by lowering the bar for the behavior of an administrative authority. The answer depends on one's political views.

Our dual analysis suggests that from the tax inspectors' point of view, there is organizational support for the proactive public disclosure, while our legal analysis shows that there is a lack of legal basis for proactive public disclosure. The dual analysis allows us to appreciate and understand the complexity of everyday tax administration by which mutually contradictory considerations of both legal and organizational character must be balanced. If the politicians are in support of proactive public disclosure, they must ensure that a legal basis be put in place, or the Ombudsman must change his definition of Good Public Governance.

\section{References}

Alford J., (2009), Engaging public sector clients: from service-delivery to co-production. Palgrave Macmillan Ltd.

Andersen J., (2014), Forvaltningsret, 8. edition, 2014. Karnov Group.

Basse M., Jørgensen 0., (1988), Fortrolighed $i$ forvaltningen, 1. edition. Munksgaard.

Blume P., (2006), Persondatabeskyttelse i forvaltningsretten in Forvaltningsretlige perspektiver. DJØF Forlag.

Boll K., (2012), Ethnography and Tax Compliance. In L. Oats (Ed.), Taxation: A Fieldwork Research Handbook (pp. 50-58). London and New York: Routledge.

Boll K., (2014), Mapping tax compliance: Assemblages, distributed action and practices: A new way of doing tax research, Critical Perspectives on Accounting, 25(4-5), 293-303.

Braithwaite J., (2003), Meta Risk Management and Responsive Regulation for Tax System Integrity, Law \& Policy, 25(1), 1-16.

Braithwaite V. (Ed.), (2003), Taxing Democracy. Understanding Tax Avoidance and Evasion. Aldershot: Ashgate Publishing Group.
Bønsing S., (2004), God skik-regler- hvem bestemmer indholdet, Ugeskrift for retsvæsen 2004B.1.

Bønsing S., (2008), Om god forvaltningsskik, Ugeskrift for retsvæsen, 2008B.242.

Bønsing S., (2013), Almindelig forvaltningsret, 3. edition, 2013. Juristog Økonomforbundets Forlag.

Evald J., Schaumburg-Müller S., (2004), Retsfilosofi, Retsvidenskab \& Retskilder, 1. edition. DJøF Forlag.

Flinders M., (2004), Distributed Public Governance in Britain, Public Administration, 82(4), 883-909.

Gammeltoft-Hansen H., (2010), God forvaltningsskik - om god opførsel i forvaltningen, Folketingets Ombudsmands beretning.

Gammeltoft-Hansen H., Andersen J., Engberg M., Larsen K., Loiborg K., Olsen J., (2010), Forvaltningsret, 2. edition. Jurist- og Økonomforbundets Forlag.

Grabosky P. N., (1995), Using Non-Governmental Resources to Foster Regulatory Compliance, Governance, 8(4), 527-550.

Koerver Schmidt P., (2015), Når multinationale selskaber skal betale en fair andel i skat - en balanceakt i krydsfeltet mellem skatteret og corporate social responsibility, Tidsskift for Skatter og Afgifter, 238.

Lamb M., (2005), Interdisciplinary taxation research - an introduction. In M. Lamb, A. Lymer, J. Freedman \& S. James (Eds.), Taxation. An Interdisciplinary Approach to Research (pp. 3-10). Oxford: Oxford University Press.

Mandela N., (1995), Long Walk to Freedom. Little Brown \& Co.

McKerchar M., (2008), Philosophical Paradigms, Inquiry Strategies and Knowledge Claims: Applying the Principles of Research Design and Conduct to Taxation. ejournal of Tax Research, 6(1), 5-22.

McKerchar M., (2010), Design and Conduct of Research in Tax, Law and Accounting. Thomson Reuters, Australia.

Mørup S. H., (2012), God forvaltningsskik og gældende ret in Forvaltningsloven 25 år, 1. edition. Jurist- og Økonomforbundets Forlag.

Mørup S. H., (2014), Forvaltnings brug og misbrug af pressen in Forvaltning og retssikkerhed, 2014. Jurist- og Økonomforbundets Forlag.

Nielsen R., Tvarnø C. D., (2011), Retskilder \& Retsteorier, 3. edition, 2011. Jurist- og Økonomforbundets Forlag.

OECD (2004), Guidance Note. Compliance Risk Management. Managing and Improving Tax Compliance (pp. 1-169). Forum on Tax Administration Compliance Sub-Group: Centre For Tax Policy and Administration, OECD.

OECD (2010), Information Note. Understanding and Influencing Taxpayers' Compliance Behaviour (pp. 1-49). Forum on Tax Administration: Small/medium Enterprise Compliance Subgroup: Centre For Tax Policy and Administration.

OECD (2013), Together for better outcomes: Engaging and Involving SME Taxpayers and Stakeholder (pp. 1-92). Forum on Tax Administration Compliance Sub-Group: Centre For Tax Policy and Administration, OECD.

Pollitt C., Bouckaert G., (2000), Public management reform: a comparative analysis, Oxford UK; New York: Oxford University Press.

Popper K., (2013), The Open Society and Its Enemies, Princeton University Press.

Revsbech K., (2010), God forvaltningsskik in Ret, information og samfund, 1. edition. Jurist- og Økonomforbundets Forlag.

Rigsrevisionen (2012), Beretning til Statsrevisorerne om fusionen af skatteforvaltningen (II), København: Rigsrevisionen.

Rhodes R. A. W., (1997), Understanding governance: policy networks, governance, reflexivity, and accountability, Buckingham; Philadel- 
phia: Open University Press.

Ryan B., (2012), Co-production: Option or Obligation? Australian Journal of Public Administration, 71(3), 314-324.

Rønsholdt S., (2012), Forvaltningsloven og god forvaltningsskik in Forvaltningsloven 25 år. Jurist- og Økonomforbundets Forlag.
Thaler R. H., Sunstein C. R., (2008), Nudge: Improving Decisions about Health, Wealth, and Happiness, Penguin Books Limited.

Torfing J., Peters B. G., Pierre J., Sørensen E., (2012), Interactive Governance: Advancing the Paradigm. Oxford: Oxford University Press. 